\title{
Teacher training workshops in India - A report
}

R. Shankar, Chair, International Geoscience Education Organisation, India, E-mail: rshankar_1@yahoo.com

Nir Orion, Professor, Weizmann Institute of Science, Rehovot, Israel, E-mail: nir.orion@weizmann.ac.il

Chris King, Professor, Keele University, Keele, UK, E-mail: chrisjhking36@gmail.com

Anish Kumar Warrier, Project Scientist, National Centre for Antarctic and Ocean Research, India (Present address: Manipal Institute of Technology, Manipal University, Manipal, Karnataka),E-mail: akwarrier@gmail.com

A. M. Narahari, Registrar, St. Aloysius College (Autonomous), Mangaluuru, India, E-mail: amnarahari@gmail.com

S. G. S. SWAMY, Executive Secretary, Karnataka State Council for Science and Technology, Bengaluuru, India, E-mail:

swamy@kscst.iisc.ernet.in

\section{General}

The International Geoscience Education Organisation organised three Teacher Training Workshops in Goa, Mangaluuru and Bengaluuru during July $2-5$, July $7-10$ and July $12-15$, 2015 jointly with the National Centre for Antarctic and Ocean Research, St. Aloysius College (Autonomous) and the Karnataka State Council for Science and Technology, which were attended by 17, 48 and 63 high school teachers respectively. These were organised as a pilot project to test the impact of such an approach in an Indian setting.

\section{The central role of the EARTH SCIENCES in the $21^{\text {st }}$ century}

One of the main challenges to humankind at the beginning of the $21^{\text {st }}$ century is maintaining the balance between human activities and nature. Unfortunately, human activity can cause imbalances in the natural earth system that puts at risk the ability of many species, including the Homo sapiens, to survive on planet earth. Earth science is the science that connects together all aspects of earth processes and the resources that are needed for our existence (fresh water, air, energy, soil, ocean and earth materials) together with the study of natural and humaninduced hazards. Earth science focuses on the understanding of the way that this complicated earth system works. Therefore, earth sciences are vital to humans in general and especially to those in India, the second most populated and a rapidly growing country in the world.

Unfortunately, without an understanding of the role of humans within the earth system (environmental insight), people of India and the entire world may face future global crises. Therefore, it is essential that every child in India becomes aware of these aspects and is enabled to grow up to be an environmentally literate and responsible world citizen. Emphasis should be laid on the earth system science approach early in the educational scheme as several issues of concern to humans are either related to or emanate from interactions of the different subsystems of the Earth System, such as aspects of the Indian monsoon, ocean productivity, cyclones, tsunamis and sea-level rise. Earth science is a truly multi-disciplinary and integrated science of the $21^{\text {st }}$ century and links economic and environmental aspects with human well-being.

\section{The scenario of earth science education in Indian schools}

Earth science, unfortunately, is neither a separate subject of study nor is it comprehensively represented in the school curriculum in India. Teachers not from the Science, but the Arts stream, teach earth science topics in schools. Teaching is mainly in the form of lectures without many hands-on and mind-on activities. Inquiry-based learn- ing and teaching skills are inadequate; as a result, students memorize facts and figures and do not observe, analyse and hypothesise. The consequence? They are unable to relate what is taught in the classroom to what they see in their surroundings. That school teachers are not formally trained in the teaching of earth sciences is a glaring omission, covering both the aspects of content knowledge and interactive teaching skills, using the laboratory, outdoors and computer-learning environments that form the heart of earth science education.

In the light of the above, the way earth science is taught in Indian schools needs a radical shift from classroom lectures to field work and hands-on activities, observations and deduction. This challenge can only be met by a systematic professional development of teachers, based on teaching materials especially tailored for the Indian curriculum and circumstances.

\section{The workshops}

The objective of the workshops was to provide the participants with practical teaching and learning strategies and techniques. The participants experienced active learning in the lab, outdoor and classroom learning environments with learning materials (worksheets and activities) that can readily be implemented in their schools.

Through the professional development workshops, the participants experienced teaching methods and learning materials that demonstrated the following aspects:

Inquiry-based learning

Earth system-based learning

Differentiation of learning for learners of differing ages and abilities

Addressing common misconceptions

Modelling of a range of Earth processes and their effects

The enhancement of knowledge and understanding of Earth processes

Integrating the outdoor environment as an integral component of learning

Using the schoolyard as a learning resource

Development of thinking skills and

The integration of emotional aspects of learning as an integral part of the learning process.

Participants were divided into two groups to experience two workshop approaches, which they experienced in turn. The workshop descriptions follow.

\section{The Rock Cycle and the Earth System - Professor Nir Orion}

The teachers received an inquiry-based booklet that included activi- 
ties from the "Thinking Science - Understanding Environment" (TSUE) - an Earth Systems Approach (ESA) program for middle and high school levels. After photos of the local environment of each of the workshops had been emailed to Prof. Orion in advance, he designed the booklet to follow the local rock cycle story and developed three different short outdoor activities for the Goa workshop, the Mangaluuru workshop and the Bengaluuru workshop. The main objectives of these short outdoor activities were for participants to make observations and raise questions concerning the local earth systems phenomena, together with the collection of rock samples. The teachers' authentic questions initiated the indoor learning sequence; during the indoor sequence they explored their own authentic samples of rocks.

The indoor inquiry-based learning involved a very rich material and equipment-based learning environment that is normally available (or should be available) in schools (e.g., beakers, test tubes, cylinders, slides, spirit lamps, rock and mineral kits, microscopes, binocular microscopes, sand, soil, ice, Plasticine (modelling clay) etc.).

The workshop started with a short introduction followed by a 2.5 hour (including 30 minutes driving time) outdoor activity in the local environment. The remaining 1.5 days were conducted in a room that was laid out for team learning for 4-6 heterogeneous teams of no more than five participants each. The teams worked cooperatively, as directed by the inquiry-based worksheet and the teacher moved between the teams and responded to questions and comments. Each part of the workshop started and ended with an introduction and summary respectively.

The participants of all the three workshops showed remarkable enthusiasm during their learning. This involved deep discussion among them of the activities and a lot of questions were raised. They took only short breaks and some of them even skipped the breaks in their enthusiastic response to the approach.

\section{'Teaching the dynamic Earth' workshops - Professor Chris King}

The 'Teaching the dynamic Earth' series of workshops involved a range of hands-on, practical activities during which the participants were invited to test the different activities and feedback on their educational value and practicability for teaching in Indian classrooms. Each workshop activity was designed to teach Earth science knowledge and understanding whilst developing critical thinking skills in both participants and the school pupils they teach.

Each of the workshops was self-contained and a free-standing experience, often with starter and plenary activities based on a workshop booklet, a PowerPoint introduction and a range of hands-on activities using readily available materials.

The workshops comprised the following:

\begin{tabular}{|l|l|}
\hline $\begin{array}{l}\text { Spot that rock workshop - for } \\
\text { 11-13 year olds }\end{array}$ & $\begin{array}{l}\text { 'Spot that rock' leads you step by step through a series of investigative practical activities that will allow } \\
\text { you to teach pupils to investigate and sort most rocks from first principles (and distinguish them yourself). } \\
\text { The techniques are then applied in describing and classifying a series of unknown rocks. }\end{array}$ \\
\hline $\begin{array}{l}\text { - The rock and soil circus workshop } \\
- \text { for 11-13 year olds }\end{array}$ & $\begin{array}{l}\text { Join our circus and explore the world! Experience how pupils might tackle an Earth-related activity. Then } \\
\text { tackle rocks and soils the scientific way. Test the rocks, test the soils - find out what they can tell us about } \\
\text { the Earth we live on. Try different interactive and hands on practical activities that spotlight rocks and soils } \\
\text { as you may never have seen them before - and enjoy the thrills and spills of 'the rock and soil circus' in } \\
\text { your classroom. }\end{array}$
\end{tabular}

- How the Earth works in your class- Bring the world into your classroom through a wide range of Earth science practical and thinking activiroom workshop - for 11-13 year ties. Consider different practical activities that teach about erosion, transportation and deposition and help olds $\quad$ you to pan for gold! Use sand and water to show how rivers work and coasts can crumble - see the grains move, see the banks collapse, think where the safest place might be. Clean up your pond water, then create your own mini water cycle in the classroom before taking the ideas back out into the 'real world'. everything - for 13-16 year olds
- Life, the atmosphere and

\section{This workshop offers you a range of activities to help you teach Earth-related aspects of the curriculum}

Life - aspects of the biology related fossils, evolution and geological time;

Atmosphere - the carbon cycle and possible effects of global warming;

Everything - well, not quite - but activities that help with understanding the need for quarrying, providing reliable energy supplies and radioactive decay and dating.

Try the activities with your students and enhance their lives, their atmospheres and - well - everything!

- The dynamic rock cycle workshop Try a series of 'hands-on' activities experimenting on and simulating the processes involved in the rock - for 11-14 year olds processes in a practical, investigative way.

- Earth science around your school - See how Earth science principles can be illustrated out of doors, often without a rock in sight, and how outdoor workshop - for 11-16 year pupils can be engaged in discussions about Earth processes and products. olds

- The Earth and plate tectonics work- The 'Earth and Plate Tectonics' workshop gets to grips with the wide-ranging evidence for the theory that shop - for 13-16 year olds underpins our detailed modern understanding of our dynamic planet - the theory of Plate Tectonics. The workshop begins with an introduction and progresses through a series of activities that are designed to help students develop their understanding. It uses several independent sources of evidence supporting the theory, including using rock and fossil evidence, seismic records, geothermal patterns, geomagnetism, and large-scale topographical features, both above and below sea-level. The workshop provides a reconstruction of plate movements over the past 450 million years which explains the record contained in the rocks of the world - involving amazing journeys across the face of our planet. It concludes by investigating some of the Earth hazards linked to plate tectonics, and how we can prevent loss of life.

- Teaching thinking Earth science This workshop uses a plastic tank to model the processes of the Earth's oceans and atmosphere and to disworkshop - for 11-16 year olds cuss these in ways to develop the thinking skills of pupils. 
Participants were introduced to the Earthlearningidea website (at: www.earthlearningidea.com) that contains a wide range of Earth sciencerelated activities specially designed for teaching in classrooms with minimal resources, and to the virtual rock kit at: www.earthscienceeducation.com/virtual_rock_kit/DOUBLE\%20CLICK\%20TO\% 20START.htm to help them remember the range of rock types they had seen and used during the workshops.

\section{Feedback from participants}

Each participant was asked to provide feedback on the workshops conducted by the resource persons (Prof Nir Orion and Prof Chris King). Participants' response was excellent. They were excited about how earth processes could be demonstrated using inexpensive, easily available materials. It was a radically new experience which, the teachers said, they would use in their teaching. At the end of the Goa workshop, the teachers gave a written request to the state and central governments to periodically organise such workshops, which would help them better teach Earth science concepts to their pupils. A teacher participant from Goa was subsequently able to convince the principal of her institution to initiate steps to start the Earth Science stream for $11^{\text {th }}$ standard.

\section{Main findings, the way forward and the benefits}

We summarise in the table below the main findings of the three workshops conducted in India, the steps that should be taken to remedy the earth science education scenario and the benefits that would accrue by pursuing the suggested steps:
We wish to thank all the institutions and individuals who helped us in conducting these workshops: the Weizmann Institute of Science, Israel; Keele University, UK; National Centre for Antarctic and Ocean Research, Goa; St. Aloysius College (Autonomous), Mangaluuru; State Council for Science and Technology, Bengaluuru; H \& R Johnson, Mumbai; Shri Ramappa, Ms Padmashree, Ms Shwetha Shetty, Mr Naveen, Rev. Fr. Denzil Lobo, Dr M. Ravichandran, Dr Rahul Mohan, Dr. Mahesh B.S., Dr Mohan Kumar and several others.

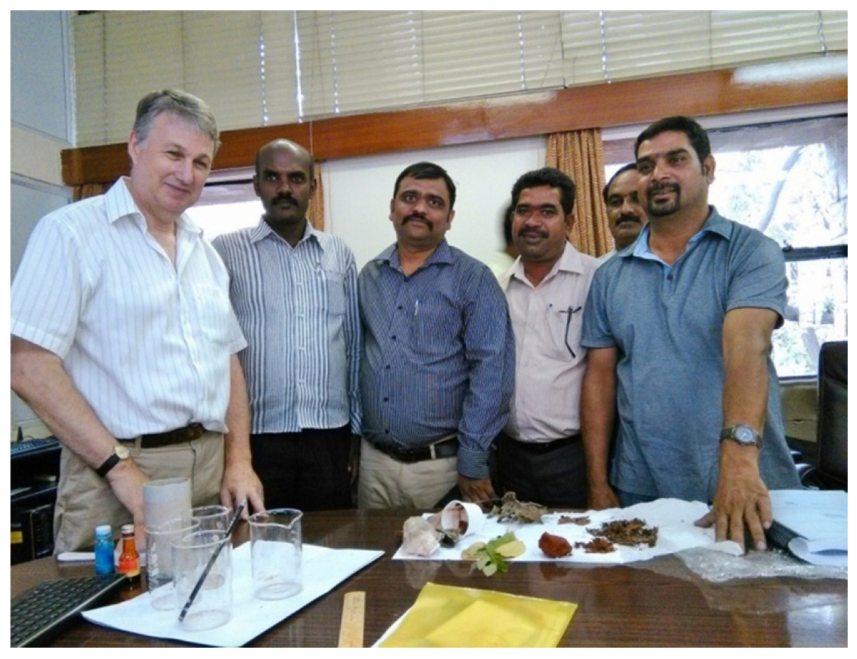

Chris King guiding the participants through an inquiry-based learning activity.

\begin{tabular}{|c|c|c|c|}
\hline & Main findings & The way forward & The benefits \\
\hline 1 & $\begin{array}{l}\text { The workshops were originally designed and } \\
\text { run in Israel and the UK. We found that they } \\
\text { worked equally well for school teachers in } \\
\text { parts of India. Both Geography and Science } \\
\text { teachers participated. }\end{array}$ & $\begin{array}{l}\text { Therefore, these workshops can be run } \\
\text { equally successfully in other parts of India } \\
\text { (and other countries too) that have a similar } \\
\text { earth science education scenario. }\end{array}$ & $\begin{array}{l}\text { Teachers in other parts of India (and other } \\
\text { countries) would be well trained to effec- } \\
\text { tively teach earth science to their students. }\end{array}$ \\
\hline 2 & $\begin{array}{l}\text { Many teachers brought to fore the fact that } \\
\text { Earth science, being a natural science, should } \\
\text { be delinked from Geography/ Social Science. }\end{array}$ & $\begin{array}{l}\text { All topics related to earth and its environ- } \\
\text { ment should be bunched as one subject and } \\
\text { may be called EARTH AND ENVIRON- } \\
\text { MENTAL SCIENCE. }\end{array}$ & $\begin{array}{l}\text { This would, without increasing the load on } \\
\text { students, (1) enable science teachers (with } \\
\text { Physics/Chemistry/ Biology backgrounds) to } \\
\text { teach Earth science; (2) give visibility to } \\
\text { Earth science in the eyes of students, peers, } \\
\text { parents and the general public; (3) encourage } \\
\text { more talented students to pursue Earth sci- } \\
\text { ence in higher education. }\end{array}$ \\
\hline 3 & $\begin{array}{l}\text { Many teachers felt that more workshops like } \\
\text { these should be organised so that more teach- } \\
\text { ers could be trained to effectively teach Earth } \\
\text { science to school students. Classroom sets of } \\
\text { samples of rocks and minerals should be } \\
\text { made available to them. Some suggested that } \\
\text { there should be workshops on other aspects of } \\
\text { Earth sciences as well. }\end{array}$ & $\begin{array}{l}\text { A National Centre for Earth Science Edu- } \\
\text { cation (NCESE) should be established to } \\
\text { produce master trainers, to design new work- } \\
\text { shops involving activities suitable for an Indian } \\
\text { setting and produce educational materials and } \\
\text { resources for schools. } \\
\text { In the meantime, similar workshops should } \\
\text { be organised in other parts of the country. }\end{array}$ & $\begin{array}{l}\text { Master trainers will train school teachers across } \\
\text { the country to effectively teach Earth science } \\
\text { with hands-on activities and motivate students. } \\
\text { Until NCESE is operational, more teachers } \\
\text { should be trained to do the same. }\end{array}$ \\
\hline 4 & $\begin{array}{l}\text { A model Earth and Environmental Science } \\
\text { curriculum should be devised for an Indian } \\
\text { setting for use by educational authorities across } \\
\text { India. }\end{array}$ & $\begin{array}{l}\text { The National Centre for Earth Science Educa- } \\
\text { tion (NCESE) should be tasked with devising } \\
\text { such a curriculum, in consultation with inter- } \\
\text { national experts. }\end{array}$ & $\begin{array}{l}\text { The curriculum could easily be incorporated } \\
\text { into current curricula and widen incentives } \\
\text { for professional development of the teachers } \\
\text { involved. }\end{array}$ \\
\hline 5 & $\begin{array}{l}\text { Workshops should be devised to directly address } \\
\text { the newly devised curriculum, accompanied } \\
\text { by published workshop materials. }\end{array}$ & $\begin{array}{l}\text { The National Centre for Earth Science Educa- } \\
\text { tion (NCESE) should be tasked with devis- } \\
\text { ing, making available and publicising the new } \\
\text { workshops, whilst ensuring that they evolve } \\
\text { over time to maintain relevance to Indian and } \\
\text { global earth-related issues. }\end{array}$ & $\begin{array}{l}\text { A structured professional development would } \\
\text { be widely offered, enabling teachers to update } \\
\text { their broad teaching and thinking skills using } \\
\text { Earth science as a vehicle for this purpose. }\end{array}$ \\
\hline
\end{tabular}




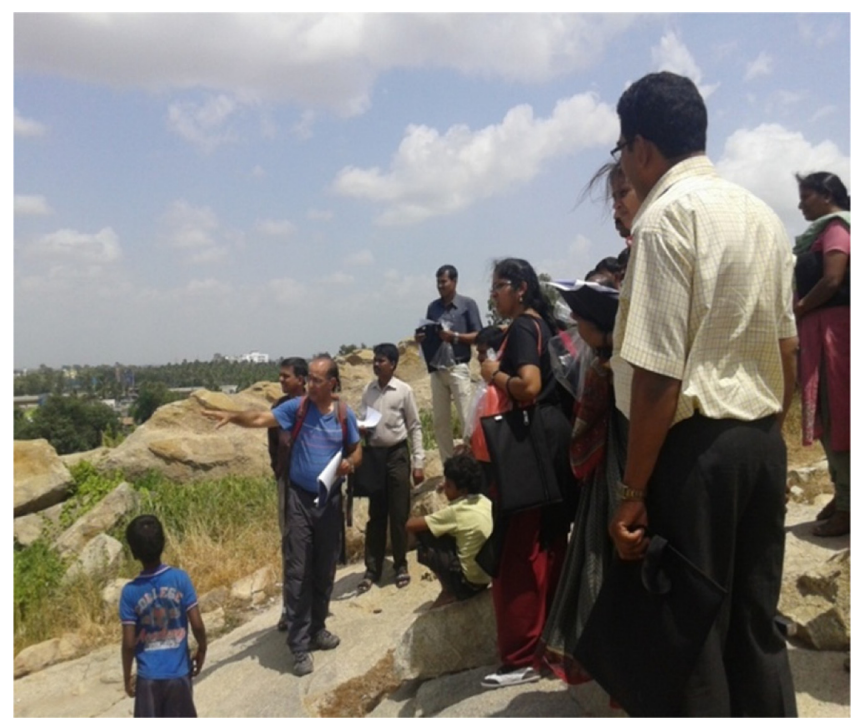

Nir Orion responding to participants' enquiries in the field.

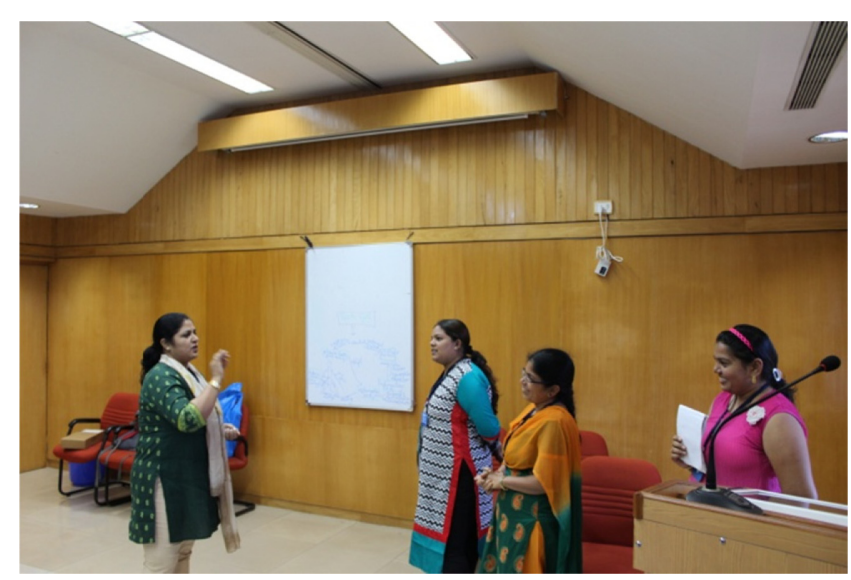

Some of the Goa Workshop participants narrating the Rock Cycle story.

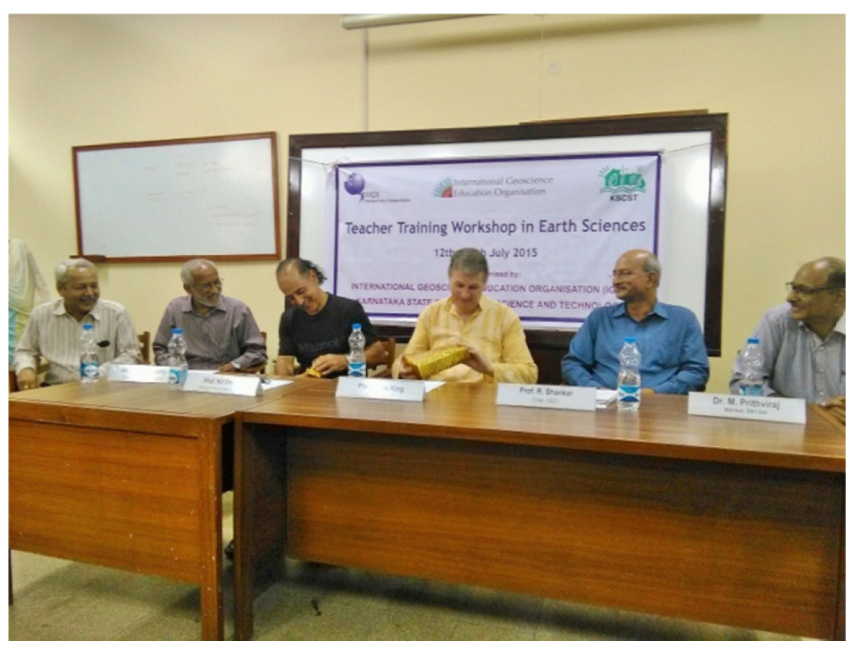

At the Valedictory function after the Bengaluuru Workshop. ( $L-R: D r$. S. G. S. Swamy, Dr. Mohan Kumar, Prof. Chris King, Prof. Nir Orion, Prof. R. Shankar, and Dr. M. Prithviraj). 